\title{
Articles
}

\section{The Invention of the Leclerc Tank: The Singular Role of a Project Elite}

\author{
William Genieys and Laura Michel \\ CEPEL; University of Montpellier 1, 39, rue de l'Université, Montpellier, CDX 34060, France. \\ E-mail:wgenieys@univ-montp1.fr, laura.michel@libertysuf.fr
}

In contrast to the abundant Anglo-American literature, little research exists in France on defense policy in general and arms procurement decisions in particular. If we seek to import models from the English-language literature, we are led to investigate the presence of a 'military-industrial complex' in France. Through the study of a specific armament policy, the development and production of the Leclerc main battle tank, we rule out the existence of a 'conscious, coherent, and conspiratorial' elite. Behind this programme, we do indeed find an elite group, but its existence is a result of the programme itself. Owing to the cold war context and the Gaullist policy of national autonomy, a group of actors benefited from relative autonomy to set down the bases of a belief in the necessity and possibility of building the best tank in the world. The programme and the elite group that sponsored it reinforced each other and succeeded in sustaining the Leclerc project after the end of the cold war context that had initially justified it. The formation of programmatic elites of this kind is one of the characteristics of the new democratic governance.

French Politics (2005) 3, 187-210. doi:10.1057/palgrave.fp.8200086

Keywords: defense policy; military-industrial complex; programmatic elite

\section{Introduction}

If there is one field of study that the social sciences in France have neglected in particular it is that of the military (Caplow and Vennesson, 2000; Revue française de sociologie, 2003). In this country, it is as if defence matters in general, and arms policies in particular, have escaped the scrutiny of research, and this despite their importance for state power in Western Europe (Tilly, 1990). For this reason, arms policies as a subject for public policy analysis and an instrument for studying the state remain a black box. This article attempts to shed some light on the subject by analysing the controversial and highly symbolic procurement of the Leclerc tank. We use this as a means of investigating the sociological dynamics at the heart of French military equipment policy-making (Genieys, 2004). Such a research perspective involves 
uncovering the role of the actors and interest groups who participate in the making of an arms policy.

North American and British empirically informed research on arms procurement most frequently takes one of two forms. The first draws its inspiration from the theory of the 'militaro-industrial complex', which postulates a high level of cooperation, or even collusion, between leading military and industrial actors (Wright Mills, 1956). In constrast, the second is driven by a paradigm of 'bureaucratic politics', which sees the state as made up of a plurality of actors that can only be studied using organisational analysis (Allison, 1971). In stressing the importance of sectoral elites, our approach used in studying the acquisition of the Leclerc tank is located at the frontier between these two schools of thought. Expanding on the critical reflections of Suzanne Keller on what goes on 'beyond the state' (1963) and in particular on the dual process of social differentiation and bureaucratisation, we show that the reality of power in the policy area we study is held by a 'strategic elite' able to act upstream of the more general 'power elite', largely by influencing the choice of policies. We further develop the notion that, beyond the well known 'grand corps', we can see, in France, the development of elite groups built around the defence of specific programmes.

The case of this piece of military hardware is also interesting because it has been presented by its promoters as 'the best tank in the world', a description that its detractors see instead as its biggest flaw. This apparent paradox can only be understood by placing this example of French military procurement within the historical context of the 'golden age of the state', which lasted from 1945 to 1974 (Suleiman and Courty, 1997). At that time, political commitment to national independence and grandeur often found its expression in the undertaking of large technology-based programmes such as Concorde, 'le plan cable', and nuclear power stations - a policy that Cohen has labelled 'high-tech Colbertism' (Cohen, 1996). In addition, arms policy-making during the period when the Leclerc was designed followed from a sectoral cognitive frame within which technological advances were supposed to compensate for the numerical inferiority of the French army with regard to the two superpowers. In turn, this sectoral cognitive frame fit well with a more global frame within which France was to be rapidly modernized with the help of the state (Jobert and Muller, 1987). The Leclerc programme thus was linked to the guiding rationality of a medium-sized country driven by a Gaullist vision of independence.

As it happened, however, the launch of the production phase of the Leclerc coincided with the fall of the Berlin wall and the dawn of an altogether new strategic era. How, in this new context, could a weapons system intended to face invading Warsaw Pact forces be justified? An analysis inspired by the realist paradigm of international relations would have justified its cancellation. In fact, it is impossible to understand an armament policy of this magnitude 
without looking more closely at the actors involved. At the highest levels of the state, these actors first proposed and backed the project, and then pushed through the decision to move to full-scale production in the 1990s, just as the strategic context was changing radically. Our purpose is to show that this selfproclaimed 'French success story' is closely linked to the role played by an elite group that not only imposed its views but defined its collective identity around and through this programme. Significantly, we suggest that this elite group is itself a product of the Leclerc programme; it did not exist at the programme's inception. Our hypothesis is thus quite different from that of the 'militaryindustrial complex' (Thiébault, 1983). Rather than the product of a preexisting integrated elite consensus, the policy that led to the construction of the Leclerc tank can be seen as the result of strategic interactions between sectoral elites and their respective logics of action, the hierarchy of the terrestrial army (EMAT), the arms commissioning wing of the Ministry of Defence - the Direction générale de l'armement (DGA) — and the Groupement des industries de l'armement terrestre (GIAT, which was a state industry) on the one hand, and the decision-making bodies within the remainder of the state on the other.

Strategic interaction between a military elite seeking the ultimate weapon (those who define operational requirements) and armament-production engineers claiming leading-edge technical expertise (those who translate operational needs into technological projects) would seem central to understanding observed outcomes. This limited vision, however, is insufficient to explain how a broader agreement was reached, bringing together an extremely heterogeneous set of actors around the Leclerc project. The dynamic leading to the elaboration of such a compromise, on the other hand, is at the heart of the 'sociology of translation' (Callon and Latour, 1991). It is through this approach, accordingly, as well as the sociology of elites (Genieys, 2000), that we seek to shed light on the political and social elements that led to the invention of the Leclerc tank. In other words, based upon an empirical study, ${ }^{1}$ this article sets out to show how the Leclerc project was indissociable from the work of a small group of actors within the arms sector who progressively formed an elite devoted to the promotion of a particular project. In this perspective, the progressive construction of a belief in the creation of the 'best tank in the world' as the structuring element of a small elite group provides the key elements that allow us to understand how this project came to be viewed as a 'success'.

\section{Towards the Invention of the Best Tank in the World}

It is important to stress from the outset that the conception and promotion of the Leclerc project are indissociable from the work of a small group of actors in 
the armaments sector. This group gradually assumed a central role in the legitimation of this project by spreading a belief in 'the best tank in the world' throughout the highest levels of the state. A mixture of supposed imperatives and the quest for 'the best weapons' (Kaldor, 1982), this belief in the Leclerc allowed it to be kept alive despite the radical transformation of the geostrategic context and of the very cognitive framework underlying French, and indeed Western, defence policy. The work on the sociology of innovation done by Michel Callon and Bruno Latour allows us to understand the concomitant structuring of this project and the heterogeneous network that sustained it (Callon and Latour, 1991). What we must examine is how the Leclerc project resulted from a process of translation in which the simultaneous definition of problems and solutions rallied the interest and thus the support of a certain number of actors from the military, scientific, 'new technologies' and political worlds. We will further see how a socio-technical network, by solidifying at a particular moment, succeeded in imposing the Leclerc project as a self-evident technological necessity.

When studying the origins of the project initially labelled the 'principal combat vehicle', one is immediately struck by the high levels of intellectual activity it entailed both within and outside France. However, the FrancoGerman cooperation, which got off to such a promising start over the 'Char 90', soon became a red herring, thus legitimating the definition of an entirely French need. In order to understand the subtle twists of this process, one needs to revisit and revise an approach in terms of the technological imperative of arms programmes, in particular its tendency to postulate the existance of a particular technological trajectory (Schoeer, 1984). Contrary to this hypothesis, our research shows how a socio-technical network led its project to victory by building belief in its technological excellence (McNaugher, 1984; McKenzie, 1990; Spinardi, 1994). Subsequently, this belief in making the best tank in the world came to be an important resource in the politics of resisting the programme's opponents.

\section{Rallying to the idea of the high-tech tank}

The origins of the initial project that later became the Leclerc programme cannot be understood solely through the prism of quests for technological innovation. $^{2}$ One first must recall that initial reflexion began at the end of the 1960s when the final studies over updating the AMX 30 were taking place. ${ }^{3}$ One military officer describes this period in the following way:

At the time the AMX/APX were pushing the idea of an AMX 40 as the ultimate version of its predecessor. But the army, and especially the EMAT, wanted to jump further ahead in order to outclass its potential enemies in 
the field. One has to remember that we were very much still in the context of an arms race. ${ }^{4}$

Even if the choice of the Leclerc was yet to be made at that stage, both the army's headquarters (EMAT) and the DGA agreed that one needed to invent a new, innovative form of a terrestrial armoured vehicle capable of taking on the armies of the Warsaw Pact. In the middle of the 1960s, the French defence policy was characterized by the desire to remain independent of NATO by developing a capacity of nuclear dissuasion (Vaïsse, 2002). Thus, reflexion about a new armoured vehicle was intended to complement other parts of a coherent defense system.

The first studies of the PCV were undertaken in 1972-1973. Even if the idea of a tank being the principal combat vehicle had yet to be decided, the experts began to produce serious engineering studies along these lines. Two types of actors from the world of the military were involved. On the one hand, there were the operational actors (army officers) led by the head of the army and assisted by the Permanent Consultative committee on Armoured Vehicles. On the other hand, there were the technicians from the arms corps, in particular arms engineers from the DGA/DAT and the AMX/APX based in Satory. These actors therefore formed two distinct working groups. The first was run by the Inspection de l'armée blindée (EMAT) within a framework provided by a sub-committee on future tanks in which engineers took part. The second was a 'reflection' group on tanks of the future (GRCF), which was closer to the DGA/DAT/AMX and made up almost entirely of engineers. ${ }^{5}$ In short, the first stage of the programme's definitional process essentially involved operationalizing a project for the army that would respond to the imperative of "stopping, in the field, the hordes arriving from the East long enough to put our nuclear weapons into operation'. At the time, it was officers from the army who were most deeply involved in defining the programme, because this process was so centred upon defining a future military need. At least until 1977, this need was defined by the military using the DGA-DAT's set of technical criteria. Given the latter's role as an 'industrial architect' and its control over the technological dimension of the project, it had to decide whether its timing and overall operationality were appropriate. But at this time, the choice of a tank as the principal weapons platform had yet to be made. Indeed, even the option of a helicopter was still being considered. How, then, are we to understand the ultimate choice to design a main battle tank and, beyond that, to aim for a technological showpiece: 'the best tank in the world?' This outcome is the result of a 'chain of translations' in the sense given that expression by Callon (1986).

It was first through a process of defining needs and 'military characteristics' that the idea of a tank as the leading combat vehicle progressively began to be legitimated. ${ }^{6}$ The selection of the 'tank option' was, in the first instance, the 
result of a process of translation intended to establish 'an equivalence, albeit always a questionable one, among the problems put forward by different actors each using a distinct cognitive repertoire' (Callon and Low, 1989). In the present case, 'stopping the hordes of the east' (problem number 1: strategicmilitary) was equated with the necessity of 'conceiving a new primary combat platform embodying a technological leap (problem number 2: technicalscientific). By asserting an equivalence between these two problems, the translation also served to identify and define the actors who would be considered as legitimate participants in the definition of both the problem and its solutions - army officers, for whom the key requirement was to surpass the enemy in operational capacity, and armaments engineers, for whom developing advanced armoured vehicles was a professional goal in its own right. This first translation brought together a first set of actors, army officers and specialized engineers, whose interests and operational logic were initially different. A second set of translations brought these actors, now allies, to accept that the conception of a high-technology tank would be a common 'necessary point of passage' in meeting their diverse needs. The hard core of the network thus constituted by a small group of engineers and military officers was in this way able to make itself indispensable by imposing a definition of the problem that eliminated all other alternatives solutions to the tank. By making physical occupation of the battlefield the principal military necessity to be met by the new 'principal combat vehicle', the network that grew up around the Leclerc discredited the competing option of a helicopter - the choice of a competing network. A helicopter, by definition, is incapable of staying in place indefinitely. This conception of the problem, thus, left no option but to conceive the answer in terms of a main battle tank, the only weapons platform able to maintain itself in place in the face of the enemy. More generally, during this phase of the definition of military need, the as yet undetermined nature of the 'future principal combat vehicle' played its role in rationalizing the choice of a tank. By making the occupation of territory captured from the enemy a central need, the solution of a tank was legitimated. Apart from the operational parameters that favoured this option, the final choice needs explaining in terms of a more purely technological dimension.

A third phase of translation allowed the stabilization of the high-technology tank option. French arms engineers, at the time, possessed considerable knowhow in the production of a number of tank components that would give the project as a whole high performance: armour, motorization, canons, turret, command systems. These engineers then worked to rally military and political decision makers around the project of conceiving a revolutionary, nextgeneration tank that would break with what was currently available in the marketplace. As of 1968, engineers based in Satory had begun to invent a very powerful motor (more than 1,000 horsepower while the AMX30 only had 700). 
More precisely, the objective was to build a motor that was both powerful and light so as to be able to use weight gains to improve armour quality. Indeed, here a technological 'leap forward' was also sought after using composite materials capable of resisting the Milan and Hot missiles to which the AMX30 remained vulnerable. The need to develop armour of a new type to protect both the crew and their equipment thus became a supplementary technological parameter used to argue in favour of new generation material. Firepower was the third challenge. As always for tanks, this was a key variable given that the 'Russian enemy' would always be numerically superior. Taken together, these technological leaps proposed by the engineers would serve to increase both the lethality of the weapon and the security of its crew - features that ensured the agreement of military planners. The solution put forward by the designers of the future tank, for example, implied designing a system whereby, for the first time ever, firing could take place while the vehicle was moving (thereby improving its level of protection). Lastly, building a 'digital tank' also became a major challenge for this project. Indeed, right from the outset, the tank was conceptualized as a digital system in its own right, again using technology that, at the time, was only available to the aerospace sector. For many commentators, this is really where the complexity of the Leclerc programme lay. Indeed, the quasi-structural innovations made in the field of digital technology meant that the programme was trapped by its own ambition to become the highest technology product possible. This is because this goal was set despite the instability of digital technology at that time. Indeed, according to several actors involved, disagreements did not occur so much over military operational questions as around the designer's table.

In 1982, after 5 years of iterative studies that sought to meet the specifications set by the EMAT, the two forementioned working groups proposed a concept, which was to provide the basis upon which a development contract could be put to the minister of defence. The factors listed above therefore fed into a process which made 'the need' for an innovative tank an 'objective' proposition. Indeed, from many points of view, this option can be seen not as an operational choice but also as one that reflected the technical know-how of French arms engineers and their scientific independence. ${ }^{7}$ It also represented a significant investment on the part of the members of the network, beyond the differences in individual logics, that served to solidify at once the network itself and the project that it advocated. From this perspective, the military and engineering experts worked 'hand in hand' going beyond the institutional constraints, which had in the past so often opposed military and technocratic elites (the ' $\mathrm{X}$ ' from the Ecole Polytechnique) whenever ambitious technological programmes had been put forward. The different protagonists interviewed considered that they had a good deal of autonomy in responding to the specfications set by the military. To this freedom of action one must add 
the high level of fit between their project and the dominant cognitive frame then shaping overall French arms policy: a Gaullist approach, which considered it imperative to adapt to threats as quickly as possible by making any technological effort regardless of its cost. This goes far in explaining the agreement, at this time, of political and administrative authorities. Strengthened by all these points, from 1975-1978 to the end of the studies carried out by the CCPEB, the head of the army, General L., opted for a tank as France's Principal Combat Vehicle. In so doing, and in collaboration with his German counterpart, he also launched the project 'char 90'.

\section{The Leclerc and French insularity}

Reflections concerning the future principal combat vehicle took on a new tonality when the prospect of launching a Franco-German arms programme was introduced. This broadening of the network was linked to the role played by President Valérie Giscard d'Estaing, whose overall strategy at the time was to reinvigorate the Franco-German partnership. The price for keeping the support of political leaders at this time, thus, became a shifting of the network towards Germany, thus enlarging it. In 1978-1979, a set of military requirements was established by representatives of both countries. As a result, the French network of experts experienced an increase in their knowledge base because their German counterparts had widely recognized experience gained in building the Leopard tank. This collaboration was particularly positive concerning research in the protection of armoured vehicles. More generally, it enabled the idea of a high-tech armoured vehicle to mature and meet all the conditions (i.e. both operational and technical criteria) for generating an innovative product. This also highlights that the desire to cooperate with the Germans was superimposed upon a project that was already firmly anchored in its sectoral institutions. In the end, however, the Franco-German project never got beyond the level of technical exchanges because it lacked political backing. Indeed, if the identification of a common need and timeframe proved problematical, on the French side it is important to underline that certain actors, in particular the DGA, but also a Trade Union strongly represented in GIAT (the CGT), were, for different reasons, partisans of a uniquely French programme, while, on the German side, there was always the possibility of developing production of the Leopard 3.

Bearing this in mind, it is important to elucidate the reasons for which launching a terrestrial arms programme as ambitious as the Leclerc can be explained by 'French insularity' ('La tentation hexagonale': Cohen, 1996). Elie Cohen has shown how the Gaullist strategy of attaining independence for France fed into the adoption of a form of 'mili-tech mercantilism' founded upon the concept of self-sufficiency first codified around nuclear weapons. 
Subsequently, as in the case of the Leclerc, this theme of self-sufficiency was extended to conventional arms.

Significantly, at virtually the same moment that the Germans withdrew from the collaborative project, the then Minister of Defence, Charles Hernu, decided to officially launch the Leclerc programme and gave it both a nationalist and statist meaning. ${ }^{8}$ All the work done beforehand on the PCV project clearly fed into this decision. The cooperative dynamic developed between actors from the EMAT and the DGA, and also during the exchanges with German actors, was a resource for supporters of the programme. The important technical know-how acquired during this period was used to convince key political actors (in particular the Minister of Defence, the Prime Minister and the President) that 'we the French' were about to produce a weapons system that was 'revolutionary' in its conception and capable of making a genuine difference in the battlefield. This was an argument that stood a high chance of rallying political support, in particular that of the Minister for Defence, in favour of the network of actors that had crystallized around the Leclerc project (Callon, 1986).

According to all the actors interviewed about this period, the question of the 'operational dimension' of the future tank was decisive. ${ }^{9}$ Many meetings bringing together the different members of the group working on the future tank and officials from ministerial cabinets were organized in order to influence the political decision-making process. In such fora, the army threw all its weight behind the proposal because its leaders considered that the tank option gave them new perspectives. A number of internal notes were produced that argued in this direction, all stressing the operational qualities of the tank. It is important to stress that the quest for a new tank capable of facing up to the armies of the Warsaw Pact became a dominant piece of rhetoric throughout the 1980 s.

A second set of arguments ensured the support of Defense Minister, Charles Hernu. The political decision that committed the French arms industry to this long-term project was entirely in keeping with the policy of 're-launching the economy' chosen by the new socialist government. Indeed, it was part of a series of big industrial programmes intended to give substance to an era of political change. As such, this political decision was also part of what a number of commentators have called 'the Golden age of the French state'. ${ }^{10}$ According to one expert on the arms industry, 1960-1990 was the golden period for this sector (Giovachini, 2000). Acting as a sectoral elite, arms engineers had a degree of influence that clearly surpassed the role of defining operational dimensions and often meant defining the need for an armament. The choice of the Leclerc was thus the result of the capacity of sectoral elites to build up a belief that this tank would be 'the perfect weapon'. Two reasons explain this capacity. The first is that the very idea that this would be 'the best tank in the world' was the result of a small elite, which, working within a favourable 
political context, managed to impose its definition of both the problem and the solution upon other actors. The second explanation is that the final political decision had both a geostrategic and an industrial dimension. Indeed, when the decision was announced, politicians found themselves having to respond to a clear need identified by the army, a need that would use technological knowhow sought after by the DGA and allow France to continue to buy itself a large arms industry. Taken together, this long process of interest building reinforced the project, and the DLD's signature by the political leadership represented a step towards its irreversibility (Callon and Latour, 1991). Through the successive episodes of translation detailed above, we witness a mobilization of actors who formed alliances and stood together to make first credible and then inevitable the belief that France was about to build the best tank in the world.

\section{Vices and Virtues of a Technological Belief}

Paradoxically, after the ministerial decision to launch a new tank programme the uncertainties regarding its implementation increased rather than decreased. Difficult economic conditions and the changing face of international relations were part of the reasons for this. Indeed, at the beginning of the 1990s, the actors in charge of the Leclerc programme had to face not only technical and budgetary problems, but also the end of the Soviet military threat. Despite all these changes, however, the autonomy developed on the basis of a belief in 'the best tank in the world' continued to be a resource with which to keep alive both the programme and the elite group that emerged around it. A first victory for these actors was the launch in 1988 of the production of prototypes. The first of these left the factory in June 1989, but the development of others continued for some time. During this period, the 'fall of the Berlin wall' heralded some major strategic rethinking and raised the question of the relevance of a tank designed to take part in a type of military operation that seemed to be becoming extinct. The second victory of the actors behind the Leclerc was the decision in 1990 to build an assembly line for the Leclerc and the creation of GIAT industries. The creation of this new industrial actor provided the arms policy with a new form of justification in allowing France to retain a capacity to produce terrestrial military equipment. ${ }^{11}$ The puzzle to be addressed is therefore why, despite all the aforementioned constraints, nobody brought the Leclerc programme to an end.

\section{A political agenda under pressure}

If the study phase that generated the ideas behind the Leclerc was not overly expensive, the next phase inevitably was; for several years it put a serious dent 
in the investment budget (Titre V) of the Ministry of Defence. The initial order was for 1,400 tanks, of which 1,200 would each cost 2.29 million euros. The economist Jean-Paul Hébert (1999) rightly points out how this initial ambition was seriously reduced, thus slowing the rate of production of the tank. ${ }^{12}$ As so often when an arms programme begins to be implemented, the challenge for the advocates of the Leclerc was to keep the production targets and timetable on track while dealing with a range of new technical challenges (Sapolsky, 1972). For our purposes, it is therefore important to show that despite an increase in constraints on a programme initially designed as a new example of Franco-German cooperation (le char 90), its implementation nevertheless became a political and symbolic objective.

Once a decision had been taken by the Minister of Defence at the end of 1982, a confidential internal document (DLD) concerning the future tank was put on the agenda of French arms policy makers. This marks the end of the experimental period even if many technical parameters were far from stabilized at that point. The implementation phase had three sub-phases that were intended to be carried out in the following sequence: (1) 1982-1986, a definitional phase; (2) 1986-1990, development; (3) 1990 onwards, industrial production. If, in the Leclerc case, these dates were formally respected in order to keep the programme alive, the process of developing the tank extended in practice into the phase of industrial production. This very tight timetable shows that from the outset the question of time was a central issue for the programme. Respecting deadlines was vital because it allowed the advocates of the programme to confront the increasingly constraining issue of financial restraint head on. Indeed, if the programme for the future tank was inscribed in the military programming law of 1982 (just as it was again in 1987), there was no guarantee that, in the future, its budget would be as big. Indeed, the general governmental policy of budgetary restrictions introduced in 1983 constituted a constant challenge to the programme. From this perspective, it is important to realize that right from the outset of the programme's implementation, two distinct economic logics within the French state began to clash: the first consisted of finding the money in order to make a highly technologically ambitious (and therefore expensive) tank; the second, pushed for by the Ministry of Finances, was to rationalize the state's budgetary choices.

This structural opposition between technology and costs led the sectoral elite supporting the programme to engage in an almost obsessional quest to save time. Indeed, even if in 1986 the Minister of Defense took the symbolically important step of naming the tank the Leclerc, the first stages of its production were difficult. In making the first six prototypes it was recognized that the tank's specifications were far from stabilized, largely because the preproduction stage had been abandoned. At the same time, launching industrial production of the Leclerc had to take place in order to respect the financial 
timetable. Indeed, at this stage it was still possible that politicians would stop the programme despite the fact that investment in the project had already been considerable. Naturally, the state's industries in the terrestrial arms sector needed this project so as to avoid an oncoming crisis. Moreover, the preparation of the launch of GIAT industries would have become problematical without a healthy order book. For this reason, the DGA/DAT made a decision that was subsequently to have many serious consequences by proposing to skip the pre-production phase. This decision gave rise to lengthy and forthright discussions within the groups of advocates for the programme:

Engineer M. had refused the option of a pre-production phase for the tank. This may seem like a detail, but if we saved ourselves some time initially, we subsequently lost three years when we had to solve all the problems that came up. We had intense discussions over this point, but the political and temporal constraints were such that we made this decision. Internal and external political constraints were very important because we could not be seen to threaten the GIAT's order books. ${ }^{13}$

Although the tests on the prototypes were not yet over, in 1991 the same group of actors then managed to obtain a political agreement to go ahead with industrial production. This political and tactical manœuvre again allowed them to save time at a key moment, despite yet again transgressing the traditional rules of arms commissioning. The reasons for this decision were not only of economic and industrial policy, but also of a symbolic character: once the Germans had withdrawn from the programme, its implementation became a test of the French actors' enduring capacity to deliver arms programmes. When interviewed, several of the actors involved considered that this tactic was valid because it allowed the programme to become durable, even if the first tanks off the line paid the price of the hurried timetable. In short, the sectoral elite behind the Leclerc allowed this issue to become confusing as a means of preventing external actors from abandoning this arms programme.

\section{The risks of producing 'the best tank in the world'}

Meeting the technological ambition of this programme turned out to be a more perilous exercise than initially foreseen, in particular because the following equation had become a mantra for the actors involved: 'for every square centimetre of armour, we need one square centimetre of electronics'. ${ }^{14}$ The first phase of producing the tank turned out to be complex because all its technological innovations had to be meshed together while testing the first 16 tanks off the production line. This was also the cause when the major components and weapons were chosen. In particular, a decision taken to split acquisitions among a number of small suppliers did not encourage their 
perenity and thus ease of maintenance (a major problem of continuity between the Leclerc series 1 and 2). Indeed, the practice of 'retrofitting' (improving equipment as it was being developed) had important consequences because it caused GIAT to introduce thousands of modifications. The first tanks produced in 1991/1993 were given a tough testing by the army and fed into this process. The engineer's desire to make an exceptional tank thus led to a considerable increase in its cost of production. Moreover, the fine-tuning of the technology took much longer than had been foreseen.

In summary, during this period the tank evolved in stages and by losing many of its common features. This is due partly to progress in computer technology, but also to problems with an air-conditioning system that initially had not been considered necessary for European battle conditions. As a result of the tank's high level of computerization, however, this question of temperature became vital. However, the advocates of the Leclerc justified the rather haphazard way of developing the tank by pointing to the technological 'coup' that they were attempting to make, in particular in order to make it the centre of a new and innovative 'battle system'. Once again, it is vital to underline the effects of this technological belief held by the group of actors behind the Leclerc. By transforming this belief into a veritable paradigm, these actors put themselves into a powerful position whenever the tank's problems were criticized either within military circles (e.g. by officers in favour of other programmes) or by organizations in charge of financial audit (Cour des Comptes, 2001). Indeed, these actors were able to make their defence of the programme more credible by reiterating the idea that they were making 'the best tank in the world'. Lastly, the change in military doctrine for land-based fighting then underway around the notion of 'battle system' was also used to justify the technological belief associated with the Leclerc. In particular, the advances in computer technology were presented as the means to enable this tank to become a cornerstone of the new systems of arms that would be brought into operation over the following few years.

\section{Behind the Leclerc Tank, the Action of a Sectoral Elite}

It is necessary to explain why the belief in the 'best tank in the world' not only became the reference point for collective action among actors arguing for this project, but also for those who actually took the decision to go ahead with the Leclerc. Indeed, many actors continued to believe in the programme despite its many financial difficulties. In this section, we develop the hypothesis that this result follows from the strategy of the hard core of the project elites made up of engineers and army officers, which progressively turned itself into a sectoral elite focussed on the defence of a military equipment project. ${ }^{15}$ This led to the 
outcome in which the elite group 'constructed' its own identity at the same time as the tank and succeeded in monopolizing expertise. In this way, it found itself able to legitimate the project as a sectoral elite. ${ }^{16}$

Through analysing the professional trajectories of the elites who managed this programme (programme officers in the EMAT, programme directors in the DGA and the GIAT), one can see how a small group of actors, partly motivated by sectoral career possibilities, consistently gave more coherence to strategies for defending the Leclerc. A tradition of professional mobility wherein actors could pass without difficulty from part of the state (the DGA) to industry (GIAT) reinforced this phenomenom. ${ }^{17}$ In this way, despite the fact that personnel involved in managing the programme changed every three or four years, the vast majority of actors who participated in the initial phases of the programme subsequently took part in it from other positions. It is particularly important to note that this occured as much for scientific elites (arms engineers in the DGA and GIAT) as for military elites (EMAT). Indeed, their professional trajectories intertwined with that of the Leclerc itself. In other words, behind the Leclerc emerged a strongly specialized and autonomous elite whose strategy within the French state led them to push for this policy. An approach in terms of the professional trajectories of transversal actors (both military and technical elites) who defined the Leclerc programme thus enables one to shed new light upon this question by highlighting the role of their know-how in the production of a belief in the programme as a whole.

\section{Converging sectoral trajectories}

In order to understand the origins of the Leclerc, it is important to show how a small sectoral elite came into being around a core of 10 persons. Initially these were specialists in armoured vehicles working for the EMAT, the DGA/DAT and two AMX/APX production sites. At the beginning of the 1970s, these persons were also involved in two working groups set up in order to launch exploratory investigations into the future 'main combat vehicle'. Four of these actors were members of the corps of arms engineers and knew each other well, in particular because at the time the industrial part of terrestrial arms production was still fully part of the DGA. Despite a separation within the latter organization between the DAT (Direction de l'armement terrestre, Ministry of Defence) and GIAT (industry), professional convenience was highly developed: 'we all knew each other because the DGA was the industrial designer of all such programmes'. ${ }^{18}$ This phenomenon had a clear impact upon the selection of the first directors of the Leclerc programme, meaning that people used to working together on the programme obtained senior posts. 
The professional and sectoral trajectory of another inspecteur de l'armement provides an additional illustration of the long-term involvement of his professional corps in this arms programme. Trained at the Ecole Polytechnique, this engineer chose to work in the arms sector at the beginning of the $1960 \mathrm{~s}^{19}$ and subsequently sought to build his career around what later became the Leclerc programme:

I spent a long time on the Leclerc. (...) I began my career in 1964 at a time when the last studies on the AMX 30 tank were taking place... and I stayed another twenty years... Initially I was working on the 'main combat vehicle' when the project itself surfaced in 1972-1973. At the time we were not yet talking in precise terms about a tank. Instead we wanted to define the military threat regardless of costs, at least this was not seen as important at the study stage. At the time we were relatively autonomous.... ${ }^{20}$

In analytical terms, this example highlights how the sectoral career patterns of arms engineers (and future programme directors in particular) took the form of personal trajectories that were strongly linked to the success of a particular arms programme. Other than the fact that they were trained in the same grandes écoles, it is this specialization in a programme that enabled them to develop a specialized form of know-how. These professional skills were reinforced by the personal connections made within the small working groups involved in programme design in accordance with the needs expressed by members of the armed forces. For these reasons, one better understands why successive directors of the Leclerc programme all shared very similar visions of its objectives and value.

The relational proximity of these sectoral elites came out during our interviews in the following way: 'you should go and see $\mathrm{Mr} \mathrm{H}$. who was also one of the programme's directors. He started with me at the Satory factories and stayed through the initial reflection stage'. ${ }^{21}$ The career trajectory of another arms engineer, who also later became director of this programme, tells a similar story. Upon leaving the Ecole Polytechnique, he first became deputy head of the division testing the AMX/APX tank before heading the tank building workshops in Angers. He completed his studies by spending two years at the Ecole de guerre before joining the studies department of the Ministry of Defence in 1988. He subsequently became director of the Leclerc programme from 1990 to 1994. This is the way he himself sums up the links between his career path and the development of the Leclerc programme:

I was involved during two quite different periods. Lasting from 1979 to 1987, the first was as head of the armoured vehicles part of the Angers factories. The second, from 1990 to 1994, was as programme director within the DAT. I was therefore involved in the origins of this tank, its development and the launch of its production. ${ }^{22}$ 
Highly representative of arms engineers within the DGA, this sectoral career path merits comparing with that of the engineers who stayed working on the programme after the creation of GIAT industries in 1991. One arms engineer we interviewed actually spent all his career within GIAT both before and after its separation from the DGA. The current director of the Leclerc programme within GIAT has a similar professional trajectory. This polytechnician became involved at the time of the break down over the Franco-German cooperation on this project. He was then involved in the first tests of the tank in 1986, before becoming responsible for developing its turret. After another period as head of testing, he took on overall responsibility for this tank within GIAT:

I've been working on the GIAT for twenty years, even if I've only been in this job for the last three. I had a similar job from 1993 to 1996. So I've worked on the initial studies, the tests and now the programme's managment. $^{23}$

In summary, analysis of the professional trajectories of this sectoral elite shows how, within the defence field, a small number of actors managed to link their careers to an arms programme. Their long involvement in this one programme led them to develop expertise and know-how that few other actors could begin to contest. Moreover, the sheer size of the Leclerc programme tended to reinforce the beliefs and the expectations of the elites who consistently defended this project.

\section{Sectoral convergence among elites around a military equipment policy}

Also present in many other arms programmes, this phenomenon is particularly strong in the case of the Leclerc where military elites have enrolled into supporting a project pushed initially by arms engineers. A traditional cleavage between 'operational' actors (the military) and 'implementors' (the engineers) was progressively reduced. Indeed, despite the many changes among those holding posts of operational command, on the military side one finds a number of officers from the EMAT who also made a long-term investment in this military equipment programme. These were junior officers, mostly trained within the Saint-Cyr military college, who chose to specialize in this arms policy by giving it considerable amount of time within the careers which their specialized training had destined them for. ${ }^{24}$ The time spent by these officers in this type of specialized branch led them to be socialized into the professional practices of arms engineers, many of whom gave courses within these training programmes. Subsequently, these were the officers who, in conjunction with the engineers, defined the operational need for the Leclerc. The study of this process highlights how this 'sectoral fusion of elites' facilitated the creation of a 
belief in the making of the 'best tank in the world'. By way of example, General D's career path can be quoted:

I am a Saint Cyrien from the 1962-1964 promotion. I joined the army itself as it was shifting its definition of the threat towards the east. I served first in a cavalry regiment driving tanks. Then I went to Jussieu where, for two years at ENSTA, I took a technical-scientific diploma. This was essentially the science of arms and where one learned about how to apply this. It was a privilege to be there which allowed me to develop relations with a number of arms engineers and people from other corps d'Etat. This 'detour' was very important for my career. Then I went to the Ecole de Guerre. After a second period of active service as a commander with the Hussards in Provins, I joined the inspections services for tanks as the head of its studies unit. It was in this capacity that I first began to think about the 'leading combat vehicle' (the embryo of the Leclerc). I thus participated in defining its military characteristics within a working group that involved colonel $\mathrm{T}$ and colonel H.... Between 1989 and 1992, I became the programme officer for the Leclerc within the EMAT and, from this position, managed the programme in conjunction with the DGA. Finally, as brigadier general commanding the 2nd DB, I got to put the tank into action. It was me that recomended that the CEMAT consider the tank to be operational in order that it could be sent to Kosovo, where it encountered great success. ${ }^{25}$

Similarly, the professional trajectory of general V, another former programme officer for the Leclerc within the EMAT and current senior figure in the DGA, also highlights the importance of the new relations between the military and engineers that emerged around the implementation of the Leclerc programme.

More generally, our sociology of the professional trajectories of the actors who 'made the Leclerc' shows how the two branches (engineers and the military), which managed the programme from the beginning of the 1990s, each possessed cross-cutting logics of professionalization. Far from producing a sterile opposition between operational actors (the military) and implementors (arms engineers), the Leclerc policy shows that, at least in such a structuring programme, institutional differences were put aside. For the actors involved, the Leclerc became much more than just another arms programme. One protagonist declared that 'it was an adventure in management, a totally new approach to tank building'. Indeed, during this consolidation phase of the Leclerc's development it became necessary for the sectoral elite to maintain the belief in the tank by struggling against internal adversaries (who said 'let's bring the quest for high performance to an end') or against financial constraints imposed by the Ministry of Finance. From this perspective, the Leclerc programme can be understood as a highly symbolic attempt to push 
forward the technological know-how that France still possessed. Indeed, this high-tech tank and its technological systems were presented as part of a new generation of arms:

I'm biased but I really do think that today it's the best tank in the world. Its mobility, its firepower and its armour have reached unprecedented heights. Moreover, this is a tank which, from the very beginning, and because of its computer content, was designed as a system. Right from 1991, it had more than thirty electronic calculators and at the time only the best fighter aircraft had this. Indeed, because of the quality of its armour, the survival chances of its crew were made very high. Lastly, this tank fits really well into a battle system (système de force). This is real modernity for terrestrial armies. ${ }^{26}$

Having shown, through our data on career trajectories, how an elite within the defence sector came into being behind the Leclerc, it is important to guage its concrete effects. Accordingly, it will be shown how these elites came to play a pivotal role in dealings with political leaders at a time when the latter needed new arguments in order to justify the decision to finance and make the tank.

\section{Beyond the Militaro-Industrial Complex, Programmatic Elites and Arms Policy}

Analysing the commissioning and implementation of the Leclerc arms programme enables one to grasp a series of transformations that have taken place within French arms policy-making over the last thirty years (Giovachini, 2000). In this particular case, the role of a programmatic elite in the decisionmaking process took a singular direction. Indeed, the influence developed by this elite around a belief in making 'the best tank in the world' highlights an internal logic specific to this sector. If one looks at the Leclerc programme using the prism of a 'military-industrial complex' one would come to the same conclusion as Edward Kolodziej (1987), when he underlined that in France this has taken a dual form: it is both statist and governed by an 'oligarchy' of arms engineers. However, our research shows that the decision to build the Leclerc was not the result of an elite group of 'conscious, coherent and conspiring' actors. On the contrary, a programmatic elite emerged around the very advocacy for and implementation of this programme. ${ }^{27}$ Around the processes of project advocacy and programme implementation, the elite group was thus progressively produced, ex post and non-ex ante, and was consolidated through the development of a specific armaments programme.

From this perspective, one is also better able to understand how the political commitment of successive governments to reduce the costs of arms programmes largely failed in the case of the Leclerc in the face of the beliefs and representations put forward by this sectoral elite. In this case, we have seen 
how a commitment to ensure the political independence of the French state by maintaining industrial capacity in the arms sector reinforced a project labelled the making of 'the best tank in the world'. Once accepted by a wide range of powerful actors, the belief in this programme allowed governments to finance it through making exceptions to the policy of budgetary austerity. By empirically studying the development of such capacities for influence over public policies one can closely observe the processes of aggregation that led to the formation of unified elite groups within the decisional levels of the state (Genieys, 2005). Indeed, this sociological and longitudinal approach to public policy-making clearly shows that the outcome of decision-making cannot be explained by simply identifying the social background of elites. Instead, one needs to generate knowledge about how elites build their respective capacities to produce representations of reality, which subsequently structure decision-making processes.

Applying the sociology of elites to this case allows us to understand how the logic of collective action put in place around the Leclerc went far beyond the simple aggregation of professional or sectoral interests. The quest for the best tank in the world was not the outcome of a competition among interests in the Ministry of Defence. Rather, it was progressively imposed as a belief, both within the elite group that bore the project and more generally. On the basis of the technical and operational knowledge of which it held the monopoly, this sectoral elite group defined the Leclerc as a programme ideally suited to the strategic interests of France. In this way, the elite network structured around this project functioned as an epistemic community whose actors shared both specific know-how and broader cognitive schemes and whose perceived expertise allowed it to influence political decision-making (Haas, 1992). Nevertheless, analysis of the Leclerc decision shows that this elite group did not owe its existence to pre-existing shared beliefs. Rather, the group and its beliefs were constructed simultaneously and then reinforced each other over time. Its central ideas were not merely 'shared sentiments' whose origins are vague, as in too many works of cognitive sociology (Muller, 2005), but rather the contingent product of a small group of actors that gradually recruited new allies while fighting against competing projects. The role of these 'programmatic' elites is thus central to the understanding of how, while governments come and go, public policies endure (Genieys, 2005).

\section{Notes}

1 Our work involved more than 30 interviews conducted with actors involved in the Leclerc tank programme (DGA, EMAT, GIAT and ministerial cabinets). The interviews were distributed as follows:

- For the Délégation Générale de l'Armement, (Ministry of Defense): two former directors, one deputy director, and a dozen specialized engineers. 
- For the Army Staff: two former Chiefs of Staff, 10 program officers.

- For GIAT Industries: one former director of the industrial group, and four directors of the Leclerc programme.

- For members of parliament: three senior members of the Defense Committee of the Chamber of Deputies and the Senate.

- This sample is representative of the actors who participated in different stages of the conception and implementation of this program. In addition, a third of them were, at some point in their career, part of the personal staff of a minister in the defense sector. This research was commissioned by the Centre des Hautes Etudes de l'Armement and published by CNRS Editions (2004). In order to respect the anonymity of our interviewees, each is represented by a letter of the alphabet.

2 By technological innovation we mean a programme that constitutes a 'technological jump' as defined by Evangelista (1988).

3 Arms policies have a temporality that is all their own based around two key moments. The first is the period of initial studies that extends up until the construction of a chain production system. This period is never less than 10-15 years. Then putting the tank into operation and selling it takes about the same length of time. This temporality has two effects. Firstly, it generates a logic of anticipation, which means that many arms programmes overlap. Secondly, it means that both the 'gestation' and the 'implementation' periods are heavily dependent upon geostrategic contexts.

4 Interview, EMAT, November 2002.

5 One of the participants in this group describes the context within which it operated in the following terms: 'At the time, we were thinking in terms of 'military needs'. The priority was to obtain a technical advantage over our potential enemies. The structuring question was: what is the enemy's tank and what must we do to gain superiority over it?'. Interview, DGA, April 2003.

6 One interviewee mentioned that "to come back to the pre-1977 origins of the Leclerc programme, when I said "one" I meant the EMAT. It was they who made the initial lists of technical characteristics where operational actors defined their need along the lines of "we want the sort of vehicle that does this sort of thing". Of course, we knew that the AMX was out of date. The helicopter was also discarded in favor of a tank for reasons of "need". Indeed, the helicopter did not fit with the same need particularly in terms of being able to maintain ground that had been captured. The theme of occupation then became central because it was argued that one had to be physically present. A tank means physical occupation of territory while flying machines only pass over it'. Interview, DGA, June 2002.

7 One of the members of the 'tank of the future' group, once a tank specialist working for GIAT, explicitly admitted to us that 'the project of a tank designed to obtain high performances in terms of motorization, firepower and armour responded perfectly to the preferred parameters of the French at the time: mobility and firepower'. Interview, DGA, June 2002.

8 In 1982 the programme to build this tank was launched, but its official name was as yet unknown. It is only in 1986 that the minister, Paul Quilès, called it the Leclerc programme. This choice is symbolic because it sent a message to the Germans. General Leclerc is associated with the liberation of France by the second Armoured Division and it thus reflected the 'reinstatement' of a strong state.

9 For one of our interviewees: "until the final decision, there was still competition between the tank and the helicopter lobbies (the latter represented by Aerospatial). But the key factor that tipped the balance in favour of the tank was the operational dimension'. Interview, DGA, April 2003.

10 In research on 'the end of the entrepreneurial state', two sociologists showed how a certain number of technological innovations, that were originally qualified as prodigious, later came to be evaluated in a more nuanced fashion because of their difficult implementation. The question 
of the role of the state's industry and its management problems are summed up as follows: 'one of the mysteries of the French state is its capacity to both set up major technological projects and then manage them so clumsily' (Suleiman and Courty, 1997, 7).

11 In critically revisiting approaches to US arms policy in terms of bureaucratic politics, John Kurth has shown how keeping lines of production open often plays a structuring role in the launch of new programmes (Kurth, 1971, 373-404).

12 According to this researcher, the initial objective was uncertain even if the figure of 1,400 tanks is often cited. The 1987-1991 budgetary law indicated an objective of 1,100 tanks, but the extra costs incurred already caused the parliamentary rapporteur on this law to lower the figure to between 700 and 800 .

13 Interview, DGA, November 2002.

14 Interview, DGA, November 2002.

15 By 'sectoral elite' we mean a group of actors who's socio-political characteristics are marked by homogenous socio-professional trajectories and the mastery of an exclusive technical know-how which has guaranteed them a relatively high level of autonomy within processes of political decision-making (Genieys and Hassenteufel, 2001; Genieys, 2005).

16 This aspect of our approach is insprired by the work of Henri Bergeron on the question of expertise in anti-drug policy. This sociologist of organizations shows that organizations demonstrate that a small group of experts imposed a psychoanalytic view of the problem of drug addiction, and thus excluded all treatments based on a substitution drug (Bergeron, 1999).

17 The central position of the DGA in the French arms sector is supported by the existence of a corps of arms engineers. Many of the latter work in the DGA, but many others work throughout the system of decision-making (ministerial cabinets; Secrétariat général de la défense nationale) and arms production. At the beginning of the 1990s, half this corps worked within the DGA and the Ministry of Defence while the other half were working for private or nationalized companies (Kolodziej, 1987; Chesnais and Serfati, 1992; Hébert, 1995).

18 Interview, GIAT industries, November 2002.

19 'It's worth underlining that at the time there was quite fierce competition to work in the arms field. I chose terrestrial arms: studies, production. Then after I moved over to the governmental side: programme management, forecasting, cooperation with other countries. This was how it worked for other corps too: one begins on the technical side so that when one moves over to work in government one knows what one is talking about'. Interview DGA, June 2002.

20 Interview, DGA, June 2002.

21 Interview, DGA, June 2002.

22 Interview, DGA, April 2003.

23 Interview, GIAT industrie, November 2002.

24 Most had been trained in the Ecole d'application spécialisée (ENSTA) or at the Ecole de Guerre.

25 Interview, EMAT, November 2002.

26 Interview, DGA, April 2003.

27 Indeed, this phenomenom occurs at precisely the time when the role of such technocrats within the state began to be widely criticized (Thoenig, 1987).

\section{References}

Allison, G. (1971) Essence of Decision: Explaining the Cuban Missile Crisis, Boston: Little Brown. Bergeron, H. (1999) L'Etat et la Toxicomanie, Paris: PUF. 
Callon, M. (1986) 'Elément pour une sociologie de la traduction. La domestication des coquilles Saint-Jacques et des marins pêcheurs dans la baie de Saint-Brieuc', Année sociologique 36: 1.

Callon, M. and Latour, B. (1991) La science telle qu'elle se fait. Anthologie de la sociologie des sciences de langue anglaise, Paris: La Découverte.

Callon, M. and Low, J. (1989) 'La proto-histoire d'un laboratoire', in M. Callon (dir.) La science et ses réseaux. Genèse et circulation des Faits Scientifiques, Paris: La Découverte.

Caplow, Th. and Vennesson, P. (2000) Sociologie Militaire, Paris: Armand Colin.

Chesnais, F. and Serfati, Cl (1992) L'armement en France. Genèse, ampleur et cồt d'une industrie, Paris: Nathan.

Cohen, E. (1996) La tentation hexagonale. La souveraineté à l'épreuve de la Mondialisation, Paris: Fayard.

Cour des Comptes (2001) Les industries d'armement de l'Etat, Paris, Les éditions des journaux officiels, octobre.

Evangelista, M. (1988) Innovation and the Arms Race. How the United States and the Soviet Union Develop New Military Technologies, Ithaca: Cornell University Press.

Genieys, W. (2000) 'Pour une sociologie comparée des élites en interaction', Revue Internationale de Politique Comparée Volume: 7(2): 467-492.

Genieys, W. (dir.) (2004) Le Choix des Armes. Théories, Acteurs et Politiques, Paris: CNRS Editions.

Genieys, W. (2005) 'La constitution d'une élite du Welfare en France dans la France des années 90', Sociologie du travail 47(2): 205-222.

Genieys, W. and Hassenteufel, P. (2001) 'Entre les politiques publiques et la politique: l'émergence d'une élite du Welfare?' Revue française des affaires sociales octobre-décembre(4): 41-50.

Giovachini, L. (2000) L'armement français au 20ème siècle. Une politique à l'épreuve de l'histoire, Paris Ellipses.

Haas, P.M. (1992) 'Introduction: epistemic communities and international policy coordination', International Organization 46(1): 1-35.

Jobert, B. and Muller, P. (1987) L'Etat en Action, Paris: PUF.

Hébert, J.P. (1995) Production d'armement. Mutation du système français, Paris: La Documentation française.

Hébert, J.P. (1999) Les exportations d'armement. A quel prix?, Paris: La Documentation Française.

Kaldor, M. (1982) The Baroque Arsenal, Londres: A. Deutsch.

Keller, S. (1963) Beyond the Ruling Class: Strategic Elites in Modern Society, New York: Random House.

Kolodziej, E.A. (1987) Making and Marketing Arms. The French Experience and its Implications for the International System, Princeton: Princeton Univetsity Press.

Kurth, J.R. (1971) 'A Widening gyre: the logic of American weapons procurement', Public Policy 19: 373-404.

Muller, P. (2005) 'Esquisse d'une théorie du changement dans l'action publique. Structures, acteurs et cadres congitifs', Revue française de science politique 55(1): 155-187.

McKenzie, D. (1990) Inventing Accuracy: A Hitorical Sociology of Nuclear Missile Guidance, Cambridge, MA: The MIT Press.

McNaugher, T.L. (1984) M16 Controversies. Military Organizations and Weapons Acquisition, New York: Praeger.

Revue française de sociologie (2003) Special issue 'Profession: militaire' 44(4): 637-798.

Sapolsky, H. (1972) The Polaris System Development: Bureaucratic and Programatic Succes in Government, Cambridge, MA: Harvard University Press.

Schoeer, D. (1984) Science, Technology and the Nuclear Arms Race, New York: Wiley. 
Spinardi, G. (1994) From Polaris to Triden: the Development of US Fleet Ballistic Missile Technology, Cambridge: Cambridge University Press.

Suleiman, E. and Courty, G. (1997) L'âge d'or de l'Etat. Une métamorphose annoncée, Paris: Seuil. Thiébault, J.L. (1983) 'Complexe militaro-industriel: notion critique ou théorique?' Cahiers internationaux de sociologie XXV: 215-237.

Thoenig, J.Cl. (1987) L'ère des technocrates, Paris: L'Harmattan.

Tilly, C. (1990) Coercion, Capital and European States ad 990-1990, Cambridge, MA: Basil Blackwell.

Vaïsse, M. (dir). (2002) Armement et Vème République. Fin des années 1950 - fin des années 1960, Paris: CNRS éditions.

Wright Mills, Ch. (1956) The Power Elite, New York: Oxford University Press, (traduction française, L'élite du pouvoir, Paris: Maspero, 1969).

\section{Appendix 1}

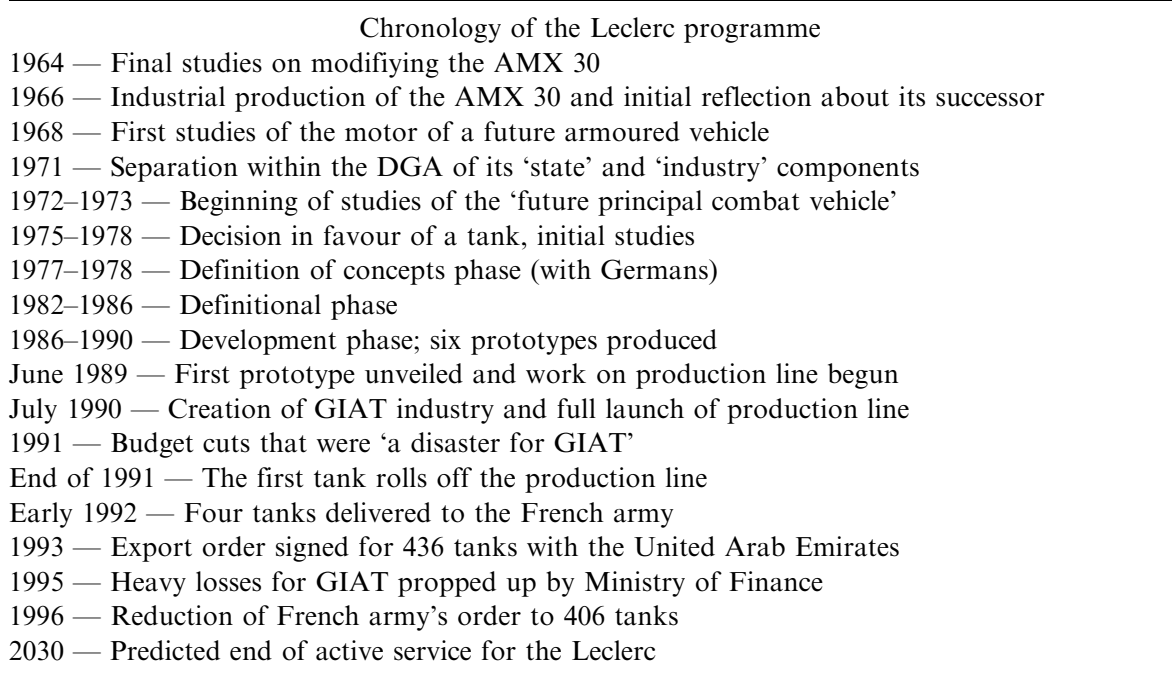

\section{Appendix 2}

Acronyms and abbreviations

ASF: Architecture des Systèmes de Forces

CCPEB: Commission Consultative Permanente des Engins Blindés

DAT: Direction des armements terrestres

DGA: Délégation Générale pour l'Armement

DMA: Délégation interministérielle pour l'armement 
DLD: Dossier de lancement développement

DSP: Direction des Systèmes de forces et de la Prospective

EMAT: Etat-major de l'armée de terre

EPC: Engin Principal de Combat

GIAT: Groupement des Industries de l'Armée de Terre

OCO: Officier de Cohérence Opérationnelle 